\title{
Discursive liberalism in the absence of constitutional guarantees in Turkey
}

\begin{abstract}
A rising liberalisation of the public discourse in Turkey has been unexpected, not least since it has been facilitated by an apparent regime change from authoritarian to liberal, and accompanied as it has been by a period of government by a religiously-rooted political party. Such a development seems to be highly affirmative for the establishment of a truly democratic regime. Even so, discursive liberalism, in the context of considerations of a new constitutional framework and settlement for Turkey, is likely to remain rhetorical unless it can be accompanied by constitutional guarantees, yet these remain some way away. The authors discuss the philosophical issues implicit in this shift, following Leo Strauss's critique of modernity, arguing that equal liberties - of politics, ethnicity or group rights, gender and belief - are likely to provide a key test of the extent to which the discourse has become politically liberal. The opportunity is there in which a truly democratic public sphere may be created, but the future of Turkey in this regard remains ambivalent rather than guaranteed.
\end{abstract}

Keywords: discursive liberalism, constitutional rights, equal liberties, waves of modernity, natural right, democratisation, military tutelage, individualism, group rights, gender equality, secularism, Kemalism, freedom of conscience, civilisational crisis

\section{Introduction}

Recently, Turkey has been facing an unexpected discursive liberalisation in public debates concerning its significant political problems. This intersects our tutelage of military, ethnic and religious questions as well as the authoritarian republican tradition. Parallel to the emergent liberal discourse, there has been a demand for a new constitution which would satisfy the claims of rights and recognition of the various segments of Turkey, which has been governed by the religiously conservative Justice and Development Party since 2002. It is clear that there is a common intent to make a new liberal constitution, supported by civil society and democratic political institutions, including governing and opposition parties, in order to eliminate the military tradition that weighed like a nightmare in previous constitution-making processes. However, there has not been any substantive development in the sense of a new social contract between equals that would brighten people's democratic future. Discursive liberalisation signals a sort of regime change from authoritarian to liberal, but the necessity of 'normative integration' amongst people via the creation of a new 'constitutional framework' does not seem likely to be accomplished soon (Arato, 1994: 92). 
The emergence of discursive liberalism provides a certain political elite and liberal intelligentsia with the power to critique some significant political taboos in Turkey. This development seems highly affirmative for the establishment of a truly democratic regime. However, what is essentially needed is a fully-fledged democratic constitution. Without establishing a constitutionally-guaranteed democratic regime, making specific the most radical principles of modernity - that is, equality and liberty, or 'equal liberties' in the Rawlsian sense - and without making the demos an actor in this process, liberties and equalities will remain the rhetoric of the political and liberal elite and will quickly fade away. Put another way, the emergent discursive liberalism, without constitutional guarantees, makes liberal freedoms partial, temporal and arbitrary; most significantly, it makes them conditional on the power of the government and on rhetorical forms rather than as legal and legitimate liberal democratic rights enjoyed equally by all.

The appearance of discursive liberalism, as a sign of a modern transformation without legal reform, seems unusual in the history of modern Turkey. The Turkish experience of modernity has, predominantly, been institutionalised through top-down legal reforms. That is to say, the desire for westernisation which has nurtured the Turkish modern experience led the modern elite to transform the legal structure without creating a vivid democratic public sphere in which demands for liberty and equality could freely be pronounced. The channels for voicing such popular demands were strictly restricted and, in reality, popular demands were not always articulated in line with a movement towards modernisation. Hence, the modern elite embraced the slogan 'For the people in spite of the people' in its reformation of the legal structure. This top-down legal tradition has been widely criticised because of its authoritarian, albeit enlightened, despotic character. On the other hand, there has always been a gap between the rights and the freedoms granted by the legal framework and the rights and freedoms enjoyed by all of the citizens.

Given this context, this article scrutinises the possibility of the development in Turkey's most recent decades of a truly liberal democratic political condition, i.e. while the religiously-rooted Justice and Development Party has been the governing party. In this process, the Justice and Development Party has been supported not only by pious people but also by the liberal and left-liberal intelligentsia. The unity between the JDP and the liberal intelligentsia can be tied to their common objection to the founding philosophy of modern Turkey, launched as it was by a staunchly secular and authoritarian elite.

In evaluating the modern experience of Turkey since its foundational wave to the present, this article refers to the theory of conservative scholar Leo Strauss on the crisisridden, dichotomous and morally paralysing character of modernity. Strauss's conservative imagination helps us understand the critique directed towards the modern experience in Turkey, while it would also reveal to us the paradigmatic difference between the liberal elite and the JDP.

\section{Modern waves in the west}

In his famous article 'The Three Waves of Modernity', Leo Strauss, a major critic and political theorist concerning modernity, conceives of the modern experience as 
being composed of three different stages (Strauss, 1989). According to Strauss's understanding, the peculiarity of modernity is defined as follows:

According to a very common notion, modernity is secularized biblical faith; the other-worldly biblical faith has become radically this worldly. Most simply: not to hope for life in heaven but to establish heaven on earth by purely human means. (1989: 82)

The first wave appears as the formation of the modern natural right tradition. This very idea of natural right paved the way for a new understanding of political and moral society. The establishment of political society through a social contract, as well as the separation of political society from individuals' private lives, is nothing other than a by-product of the transformation of political and moral understanding in modern times. This first wave also witnessed the emancipation of reason from the tutelage of divine revelation, which has been a phenomenal and yet instrumental development.

Nevertheless, this instrumentalisation has been criticised by Rousseau, who was accepted as the pioneer of the second wave. Pippin underlines:

Rousseau sees for the first time how much had been lost in the first modern wave, especially sees the Faustian bargain, how modern man had sacrificed virtue for ease, and had acquired freedom only freely to traffic in goods and money, to trade, to acquire, to lose himself in idleness.

(Pippin, 1992: 459)

Accordingly then, the rise of the second wave of modernity can be understood as a response to the crisis of the natural right tradition. Strauss indicates that the second wave is an answer to the natural rights tradition's problematic individualist and subjectivist character. That is why it is based on reason's law-making capacity, which conceptualises both rights and responsibilities in an objectivist and universalist sense. Jean Jacques Rousseau's 'General Will', Immanuel Kant's 'Moral Law' and Friedrich Hegel's 'Geist', albeit with their significant differences, should be understood as similar attempts to resolve the possible pathologies of liberal natural right on the basis of human beings' rational nature. Therefore, this wave aims to transcend reason's instrumental nature in a way that should comprehend itself as a norm-giver. That period led to the radicalisation of reason such that the truth of reason can be politically employed in order to deny the discourse of natural right.

According to Strauss, the third wave of modernity, including historicists, romantics and Nietzsche, refers to radical criticism of reason's norm-formation capacity. The questioning of reason's universal capacity has been the basic problem of late modernity, particularly after the Second World War. It is clear that, for Strauss, modernity is founded upon the internalisation of the sources of morality within human subjectivity and, as the necessary consequence of this, the oblivion of nature and the total historicisation of all moral and political standards. That is to say, the crises-ridden character 
of modernity arises from the nihilism and relativism that lies at the heart of modernity. ${ }^{1}$

It is also significant to note that, for Strauss, it is very hard to understand modernity as a single project. In his own words:

Nothing is more characteristic of modernity than the immense variety and the frequency of radical change within it. The variety is so great that one may doubt whether one can speak of modernity as something which is one. (1989: 83)

In what follows, the varieties of modernity in the Turkish context are analysed in order to clarify recent transformations concerning political problems and public political debates.

\section{Modern periods in Turkey}

The tensions of modernity in the Turkish context can best be understood by referring to an interesting incident in the 1930s when the second period of modernity was launched by republican modernisers. The incident was circulated by a significant scholar of Islam, İsmail Kara (2011), in his collected essays Turkey in the Dream of Sheik Efendi. Here, Kara conveyed a dream of Sheik Rahmi Baba, who had lived during the late Ottoman and early Republican periods of Turkey.

In the 1930s, at a time when the Republican modernisation process was in full force at societal level, Sheik Rahmi Baba invited friends among the ulema (religious scholars) to a small Anatolian town for a secret meeting. The main reason for the invitation was the Islamic devotional act calling on one of the names of God, Ya Kahhar, which literally means 'the Subduer', in the process of praying for the destruction of Mustafa Kemal and his republican regime because of its anti-religious and pro-western sentiments. The invitation was well-received and many ulema came together secretly in the town. A few hours before the morning prayer and cursing ceremony, Sheik Rahmi Baba had a dream that overturned the whole plan. In his dream, he saw a world map in the middle of which was located Turkey. The Turkish land on the map was remarkable by its overwhelmingly green colour; yet, its boundaries were in black. The black wall was thick, but it was not high at all. In the dream, the Prophet Mohammed was portioning out the world's lands to be governed. Mustafa Kemal was located in the Thrace part of Turkey, looking rather faint-hearted and uneasy. The Prophet, without looking at Mustafa Kemal's face, commanded 'Give this (land) to that (person)'. The land was Turkey and the person was Mustafa Kemal. Apparently, the dream was astonishing and the sheik was shocked: he felt divided between his intention and his dream.

It is well-known in Sufi Islam that dreams are not meaningless, but their interpretations differ from a Freudian perspective. They are considered as accurate sources of knowledge in the guidance of worldly life; a sort of holy touch on the mundane lives of true believers. After morning prayer, then, with the praying community expecting

1 Robertson (1998: 1-2) explains that Strauss's understanding of modernity in three waves can be interpreted as the 'Stages by which the fundamental nihilism that was implicit in the origins of modernity came to appearance.'. 
to start the $Y a$ Kahhar recitation to ask Allah for the destruction of the republican regime, Sheik Rahmi Baba shared his dream with the community and they interpreted its meaning as follows: Turkey is so green that it should be interpreted positively on the grounds that green symbolises Islam. The black and thick boundary was troubling, because black symbolises blasphemy. However, the boundary was not high, so the community interpreted it positively in the sense that it would easily be overcome. The posture and gesture of the Prophet and of Mustafa Kemal seemed to them negative that is to say, the Prophet did not approve of what had been done by Mustafa Kemal, and Mustafa Kemal was not looking so proud before the Prophet - but they eventually decided to respect the decision of the Prophet: Turkey was to be given to Mustafa Kemal, and thus the republican reforms should be patiently tolerated rather than being cursed since, eventually, Turkey would be on the right track (Kara, 2011: 15-16).

Looking back, as well as to the dream's future, one can detect different periods of modernisation and liberalisation in the Turkish context. Republican modernisation corresponds not to the first, but to the second, period of the Turkish experience of modernity. The first period started before the collapse of the Ottoman Empire. In the late imperial time, Ottoman intellectuals, religious scholars and the ruling elite supported the modernisation process, despite their differing understandings of modernity and the methods of modernisation.

The first period of the modern experience was partial, instrumental and superficial. 'Saving the state' reflected the underlying mentality in the appropriation of modern institutions and reforms. Beyond instrumentalism, those who aimed to engage in the intellectual tools of modernity found an almost unbridgeable gap between modern ideals and societal conditions and people's expectations. Despite the various problems of the imperial order, it is possible to argue that, in this period, the terminological tools of the modern experience had been introduced into the imagination of the intelligentsia, if not the people of Turkey. The terminological heritage of this first period includes the following significant modern forms: popular sovereignty; limited government; natural right; and so on. ${ }^{2}$

The second period of modern experience corresponds to the republican era when more coherent and complete modernisation attempts were initiated. This process was also remarkable for the eradication of traditional religious effects in the political structure, thanks to staunch secularist regulations which attracted a great deal of reaction from the religious elite and from pious people. In this sense, Sheik Rahmi Baba and his circle reflected the anti-republican and anti-secular sentiment of the 1930s. The second period of modern experience radically invested in the capacity of human reason while also cheering its contribution to the religious and scientific transformation. In this connection, the republican period prioritised reason and science as a source of human development in the sense of conquering nature and determining human destiny. In this sense, confining religious doctrines to private lives, as well as eliminating the political and judicial power of religious belief, had been central in the secular and scientific organisation of public life.

2 A coherent analysis of Ottoman modernising ideas can be observed in Şerif Mardin (2000) and Erik J. Zürcher (1984). 
The basic legal reforms involved in establishing a reason-based order were tied to the abolition of the caliphate; the unification of education; the closure of Sufi orders and madrasas; the adoption of the Latin script instead of the Arabic; the encouragement of a western dress code; the adoption of modern western laws in criminal and civil spheres; and the elimination of Islam as a state-backed religion. Mustafa Kemal Ataturk's view that 'The true guide in life is science' was reflected in the direction of the republican period.

And yet, without the dissemination of the transforming power of reason amongst the people, as the sovereign subject of the nation, the crisis-laden character of modernity in the Turkish context created a more radical recourse to reason in the guise of secularism, a secularism that reflects an aggressive will to modernise by dividing society between the modern Euro-centric elite and the traditional pious people. The modern elite assumed the role of enlightening the so-called 'backward people' who were deemed essentially and naturally good but manipulated by traditions and superstitious beliefs. A more Rousseauan 'forced to be free' understanding developed, in the sense that the true path was to be drawn by the enlightened elite (as the legislator figure in Rousseau's Social Contract), for whom reason became concrete in the legal reforms to be followed while breaking with superstition, bigotry, ignorance and darkness. The laws made by the modernising elite had been compatible with general modern philosophy, which calls for autonomy and the freedom of each and every individual member of society, in the sense of bringing modern liberties and equalities, but the duties, responsibilities and exigencies were, in practice, rather imposed. The idea of 'forced to be free', which underlines the idea of social autonomy in this sense, differs in the Turkish context. Social autonomy, as Steven Affeldt underlines, requires:

First, that, the laws of a just state must be laws that express and ensure the conditions of individual autonomy and, second, that since the laws of a just state to express and ensure the conditions of individual autonomy, to force individuals to conform to those laws will be to infringe their natural freedom but in the service of making them morally free. (Affeldt, 1999: 303-304)

However, in the Turkish context, the 'forced to be free' argument did not encourage the principles of individual and social autonomy, since the liberal democratic character of modernity was not realised. On the contrary, a significant part of the demos was estranged from republican modernity because of its enlightened despotic and secular character. Beyond the Turkish modern context, when modernity in general and its reason-based philosophy in particular has become the target of theoretical criticism, estranged and silenced groups had a niche from which to voice their long-awaited reactions. In other words, deconstruction and post-modern critics on modernity paved the way at the theoretical level for anti-republican and anti-secular Islamist groups to empower their religious identities and discourse, as well as to allow them to make connections with liberal groups. Consequently, the third period of modern experience was launched by discursive liberalism. 


\section{The third period of modernisation in Turkey}

Here, in referring to liberalism we do not mean its deep and enriched versions within the liberal tradition of political thought. Rather, we refer to its usage in political public debates as a political discourse, characterised by its emphasis on the 'relationship between the individual and the state' in order to prioritise individual liberties. The main way of supporting liberties is seen as constraining the power of the state (Kymlicka, 1989: 1). Underlining the constraint is the idea that, in a liberal society, the state should not impose a specific lifestyle and conception of good on anyone, so the members of that liberal society may be free to choose their own moral norms, religious beliefs, individual values and life goals (Sandel, 1998).

In general, liberalism articulates certain political ideals, including primarily individualism which is defended, in opposition to social groups and collectives, on the grounds that each and every individual is unique, having equal moral value regardless of differences. In this sense, liberalism aims to pave the way for individual development in terms of the individual desires and capabilities of each one. Individual rationality is also self-evident and via which each and every individual pursues his or her own conception of a good life. In addition, pluralism is very central in liberal political philosophy, in line with the belief that individual liberties and social development require tolerance and a recognition of cultural, religious, moral and political diversities. And yet, all these principles are tied to the principle of constitutionalism since, without constitutional guarantees, there would not be liberties and order provided by a limited government (Heywood, 2007).

By discursive liberalism, we mean the rhetorical dissemination of liberal political principles and the articulation of liberalism as a legitimate political ideology in public debates. In this sense, our analysis deviates from the established models of discourse theories, such as those developed by Lacan, Saussure and deconstructionist theorists who deal with language as a symbolic system. Bakhtin, Foucault and Bourdieu's models of discourse theory, on the other hand, consider language as social practice (Fraser, 1992: 177). It also differs from the new discourse theory of Laclau and Mouffe, inspiring, from a Gramscian critique of Marxist orthodox articulates, a horizon for radical plural democracy (Torfing, 1999). Despite their differences, various models of discourse theories are critical in exposing the power of words and the semiological struggles which have significant political ramifications.

In this article, we are looking for the political ramifications of discursive liberalism in the last decade of Turkey, when the Justice and Development Party came to power and since which time has continued to become a single-party government. The Justice and Development Party defines itself as a conservative democratic party, but it has greatly benefited from the discursive tools of liberalism, as well as the individual and intellectual support of the liberal intelligentsia. In fact, the relationship between liberals and the Justice and Development Party is better defined as mutual support on the grounds that liberal intellectuals, for the first time in the history of Turkey, have become popular and esteemed as 'men of wisdom'. The rhetoric of liberal democratic principles has contributed to the liberalisation of public debates, especially given the presence of four main argumentation lines which are inherent in Turkish politics. The themes of discursive liberalism in Turkish politics can be underlined as follows: 
1. liberalisation of the political sphere via the elimination of the military tutelage and the democratisation of the military/civil society relationship

2. liberalisation of the Kurdish question as an ethno-political problem

3. democratisation of the gender question (particularly in the sense of the development of women's equal rights and the partial liberalisation of the debate on the approach to LGBT issues)

4. liberalisation of the relationship between state and religion (particularly in the sense of a moving away from assertive to passive secularism). ${ }^{3}$

\section{From the military tutelage to political equal liberties}

The military's political interests go back to the Ottoman Empire, while the founders of Republican Turkey, including Mustafa Kemal, had started their military career as Ottoman soldiers. After modernisation and secularisation zeal had pervaded the modern bureaucratic elite, the military's self-imposed political role, which Haynes has defined as the 'hyper-secular' defence of Mustafa Kemal's revolution, has been the justification for military interventions in Turkish political life (Haynes, 315). Indeed, Turkish politics has witnessed major political involvements from the military: in 1960, 1971, 1980 and 1997. However, following the electoral success of the Justice and Development Party, there appeared a hope for liberalisation (democratisation) amongst the liberal and left-liberal elite.

Some scholars detect the Justice and Development Party's concept of hizmet politics (politics of services) as the 'realisation/materialisation of liberal politics' on the grounds that, instead of dealing with identity politics, and in contrast to a centralising religious identity in defining politics, the Justice and Development Party has preferred the 'politics of services', connoting 'compromise and co-operation' rather than 'conflict and confrontation' (Yavuz, 2006: 2-3). Other scholars underline the liberalisation and democratisation of politics not because of the rhetoric of service circulated by the JDP, but because the transformation of the military structure, in itself and by itself, in turn affects the political structure positively. That is to say, some scholars, including Satana, argue that political parties and political elites are not necessarily the chief actors of liberal democratic consolidation in countries like Turkey, where there is 'the legacy of a historically modernizing military' (Satana, 2008: 358). The military, then, has transformed itself which, in turn, has helped the liberal democratic consolidation in Turkey.

This transformation is in line with an international paradigm change in the military framework from combat-orientation, with less sophisticated skills, to professionalism, managerialism and diplomat-statesmen skills. The military elite in Turkey has stuck to the new framework, although the transformation has been slow. However, Satana argues that:

Any suggestion of absolute military disengagement from politics is unrealistic for countries like Turkey. (2008: 358)

3 Ahmet Kuru comparatively analyses various forms of state and religion relationships, using the concept of 'assertive secularism', as in France, and 'passive secularism' as in the US. See both his article (2007) and his book (2009). 
Despite various factors enclosed by scholars, it is possible to observe three major factors that help limit the power of the military tutelage in Turkey (Akça and Paker, 2013: 78). These factors can be summarised as the international political framework; the ethno-political framework; and the electoral-political framework. All these factors, if combined with liberal democratic political principles, mean that there would not be a return to the military tutelage. Ultimately, it is important to underline that eliminating the military tutelage is significant; however, it is only a negative move to open a democratic space for each and every citizen, who requires rather more positive tools to act freely in an established democratic culture.

\section{From the Kurdish question to ethnicity-oriented equal liberties}

Discursive liberalism incorporates the Kurdish issue as an ethno-political problem - a problem rising in the second wave of Turkish modernity and denied in ethnic terms but integrated as regional, educational and economic but, for the most part, religious backwardness. In the third wave of the modern experience, the Kurdish question started to be defined in proper terms in the public sphere. Yet, it is known that the liberal political thought tradition essentially centralises the rights and dignity of an individual rather than seeking to defend group rights in the first place. However, in the most recent decades, multiculturalism and liberalism started to be approached as one on the grounds that the rising demands of many individuals are connected to ethnic, religious and migration-related group rights.

At the theoretical level, the debate over individual versus group rights continues but, in the Turkish context, a rich discursive field has opened in debating the Kurdish question. The AKP side-stepped the ethnic question in its first period up to 2007, since its main target at the time was the military tutelage. Subsequently, the AKP managed to empower itself both in electoral terms and in opposition to the military tutelage, while its will to empower itself further by integrating ethnic difference via the dissemination of a religious discourse, but (more significantly) via the dissemination of the discourse of shared economic growth and material opportunities, seemed to have paved the way for the opening of the most liberal discursive field in debating the Kurdish question. For the first time in the Turkish public sphere, the imprisoned leader of the Kurdish separatist movement gained public legitimacy as an actor whose ideas and political messages are openly discussed by the state power.

Even so, the peace process goes back to an earlier period; the leader was captured in 1999 but the Kurdish separatist movement had soon declared a ceasefire by giving up its desire to establish a separate Kurdish state in favour instead of 'living in a democratic Turkish Republic' gaining ethno-cultural rights in the process (Yeğen, 2011: 75). Subsequently, the violent character of this significant ethno-political problem has not been completely eliminated, but a slow and yet crucial political transformation has nurtured a hope for peace and togetherness as opposed to a fear of separation. Whether hope turns into truth will depend on whether the discursive liberalisation of the ethnopolitical question is resolved by the legal structure as well as strengthened by the normative consent of ordinary citizens. 


\section{From patriarchy to gender-based equal liberties}

Gender equality has always been a major part of the modern experience in Turkey. In the second wave of modernity, women's rights and equality had been instrumental in the radicalisation of reason, while people's 'forced to be free' understanding regarding the eradication of religious norms brought the adoption of the modern laws of western countries. The republican state acted as a feminist state in transforming especially the family code, which was unique within a Muslim-majority context, although this was not a genuine call for gender equality because the modern political elite demanded that Turkish women be 'progressive', in contrast to the 'backwardness' of traditional pious women, while maintaining patriarchal tutelage in the new life of the family. In this sense, to use Deniz Kandiyoti's phrase, women were 'emancipated but unliberated' in this second wave of modernity (1987: 317).

Here, in the third wave of modernity, there is the opportunity for both the emancipation and the liberation of women on the grounds that women's full equality has, in the legal sense, been achieved. Yet in social as well as institutional life, women's powers are limited; on the contrary, violence against women has increased in a backlash to women's legal empowerment and equality. The discursive field is, however, promising on the grounds that gender equality is defended and supported not only by the liberal elite but also in that most people give consent to women's rights while, within the public sphere, discrimination against women and hate speech which degrades women are always noticed and usually objected to.

\section{From assertive secularism to belief-related equal liberties}

In the second period of modernity in Turkey, the separation of religion from the political public sphere, from the legal structure as well as from the scientific-pedagogical field, was seen as inevitable in order to catch up with the level of contemporary civilisation, namely western modernity. The dichotomy between progress and regress was made in order to imply that progressivism required secularism, whereas traditional religious affairs, which transcend the private sphere to pervade the political, legal, social and theological dimensions of life, connoted regress. Interestingly enough, in his article titled 'Progress or Return? The Contemporary Crisis in Western Civilization', Strauss criticises the modern meaning of progress as opposed to regress; he particularly objects to the substitution of the:

Distinction between progressive and reactionary for the distinction between good and bad. (Strauss, 1981: 27)

For Strauss, progress has become a problem in current western civilisation and he added that:

It could seem as if progress has led us to the brink of an abyss and it is therefore necessary to consider alternatives to it. (Strauss, 1981: 17)

In the search for alternatives, as well as objections, to modern reason and the idea of progress, the emergence of postmodern theories in the Turkish context went hand- 
in-hand with religious awakening and criticism of the foundational philosophies of modern Turkey. In this sense, Kemalist political modernity, with its central assertive and aggressive secularism, has become the target also of the liberal intelligentsia.

Discursive liberalism has incorporated the religion and secularisation debate by underlining the necessity to liberalise the public sphere from secular authoritarianism, particularly when it comes to the point of transgressing individual rights and freedoms, such as the right to education for young women wearing religious headscarves at universities. The long-term electoral success of the religiously-rooted Justice and Development Party, whose leading figures are practising Muslims and whose wives wear religious headscarves to underline their piety, has, along with the global political and theoretical transformation of modern experience, channelled and shaped the third wave of modernisation of Turkey towards a modest secularism which makes religious concerns less politicised and where Sharia is still not yet the source of legal structure. This does not mean that the Justice and Development Party does not refer to religious discourse; on the contrary, citing verses from the Koran has become a normal part of its political rhetoric. However, this rhetoric has not yet been transferred into legality; instead, the modern state's radical claim over religiosity is curtailed to the point of passive secularism. The religious rights of the Sunni Muslim majority are secured and the Diyanet ${ }^{4}$ as an institution basically serving Sunni Muslims, has maintained its status as a major state institution. The rights of religious minorities have been successfully integrated into discursive liberalism although their legal rights, as well as financial support for minority belief systems, are not guaranteed. In particular, the right to speech for non-believers is limited; for the most part, anti-religious ideas are condemned as hate speech.

Given the openness of the liberal discursive field, if the balance of respect for both religious and anti-religious ideas, for both major and minor religiosities, is secured, and if the proliferation of ideas, expressions and belief forms and practices is allowed, then this discursive liberalism may yet turn into a genuine constitutionally democratic one.

\section{Conclusion}

In this article, we have witnessed the rise of discursive liberalism in the public political sphere in the most recent decades in Turkey. Discursive liberalism has launched a relatively democratic condition for public debate, by making the political and intellectual elite voice their criticisms of the political authoritarian culture prevailing in the public sphere. Furthermore, discursive liberalism has conveyed four significant lines of argumentation that would, eventually, lead to politically liberal equal liberties.

The first equal liberty line of argumentation may be referred to as political equal liberties. In the Turkish historical and politico-cultural context, the most crucial problem that has ended political equal liberties may be identified as the 'military tutelage'. In political life, the military has deemed itself to be a legitimate political actor in sup-

4 For a detailed analysis on the Diyanet, see İştar Gözaydın (2009) Diyanet: Türkiye Cumhuriyeti'nde Dinin Tanzimi in which the author explains the way in which the secular state used religion for its secular purpose. 
porting the foundations of the republic, saving secular values and strengthening Turkish nationalism whenever it seemed necessary. Instead of limiting itself to the liberal watchdog function of providing national security, the military has assumed for itself the ideological role of occasionally fighting on a domestic front, as opposed to the legitimate political actors of truly democratic regimes; such as against university students who ask for a better democracy; against trade unionists who fight for better pay; and even against democratically-elected legitimate governments. With a curtailment of the military tutelage, we may hope for a more democratic regime in an institutional as well as practical political sense. The rhetoric behind this hope is rich, thanks to the liberal intelligentsia and a religiously-rooted governing party, which had been the direct target of military tutelage in the past, but the constitutional guarantees are not yet established.

The second line of argumentation launched by the rising discursive liberalism is ethnicity-oriented, or group rights-based equal liberties. Here, it may be shown that the Kurdish question has dominated the discursive field and, nowadays and for the first time, there appears to be a hope for peace via the transformation of an ethnicallyoriented separatism into a legitimate political field through a cultural rights-based discourse. The problem, however, is that the whole process is operated through the political and intellectual elite; ordinary people seem to be passive actors, listening to and accepting what is to be done.

The third line of argumentation for equal liberties is in the area of gender-based equal liberties. Here, women's equality has become an issue for which many willing champions are ready among the political parties, while legal reforms have also been instituted, but the social and institutional context proves the continued existence of inequality, which is mostly reflected in rising violence against women, the low level of participation of women in positions of political power, the low share of women in economic wealth, and so on. In addition, violent discrimination against sexual minorities is obvious; however, their equal liberties do not constitute an agenda even within the discursive field. Needless to say, gay marriage is taboo. The problem here is multifaceted, since sexual minorities are subjected to almost every kind of discrimination including primarily sexual but also economic, institutional, social and familial. Without a complete struggle against various patriarchal forms and homophobic deeds, genderbased equal liberties cannot be achieved even within the discursive field.

And finally, belief-related equal liberties are crucial because the second wave of modernity has made a structural distinction between traditionally pious and secular Muslims. The result has been that pious people and the religious elite, constituting a majority of citizens, have felt excluded and silenced. This does not mean, however, that they have been anti-modern in every sense; their integration as regards the modern experience has been different and their alternative path has not been diametrically opposite to the modern experience, but has been rather exposed leading to a struggle with the very nihilistic character of modernity underlined by Strauss. In the Turkish context, this has resulted not in an abandonment of secularism but a revision of it in order to create a more religious-friendly public life, thanks to the religiously-oriented struggle of the political actors and to a discursive liberalism which has converted religious de- 
mands into liberal ones by operating the idea of a plurality of conceptions of a good life, as well as of rights of expression and choice.

To conclude, the rise of discursive liberalism has created an opportunity for a truly democratic public sphere. However, the democratic future of Turkey is ambivalent, rather than guaranteed. This opportunity requires constitutionally-guaranteed equal liberties, principles of justice and a plurality of good life conceptions. Furthermore, the constitution should be based on an overlapping consensus of the political actors that reflects the diversity as well as the unity of the genuine democratic demos.

\section{References}

Affeldt, Steven G (1999) 'The Force of Freedom: Rousseau on Forcing to be Free' Political Theory 27(3): 299-333.

Akça, İsmet and Evren Balta Paker (2013) 'Beyond Military Tutelage? Turkish Military Politics and the AKP Government' in Ebru Canan Sokullu (Ed.) Debating Security in Turkey: Challenges and Changes in the Twentieth First Century Lexington Books.

Arato, Andrew (1994) 'Constitution and Continuity in the East European Transitions Part I: Continuity and Its Crisis’ Constellations 1(1): 92-112.

Arato, A and E. Tombuş (2013) 'Learning from success, learning from failure: South Africa, Hungary, Turkey and Egypt' Philosophy and Social Criticism, pp. 1-15.

Cizre, Ümit (2011) 'Disentangling the Threads of Civil-Military Relations in Turkey: Promises and Perils' Mediterranean Quarterly 22(2): 57-75.

Gunnell, John G (1985) 'Political Theory and Politics: The Case of Leo Strauss' Political Theory 13(3): 339-361.

Fraser, Nancy (1992) 'The Uses and Abuses of French Discourse Theories for Feminist Politics' in Nancy Fraser and Sandra Lee Bartky (Eds.) Revaluing French Feminism: Critical Essays on Difference, Agency and Culture Indiana University Press.

Gildin, Hilail (Ed.) (1989) An Introduction to Political Philosophy: Ten Essays by Leo Strauss Wayne State University Press: Detroit.

Gözaydın, İştar (2009) Diyanet: Türkiye Cumhuriyeti’nde Dinin Tanzimi İletişim: İstanbul.

Hale, William and Ergun Özbudun (2010) Islamism, Democracy and Liberalism in Turkey: The Case of the AKP Routledge: Oxford and New York.

Haynes, Jeffrey (2010) 'Politic, Identity and Religious Nationalism in Turkey: From Ataturk to the AKP' Australian Journal of International Affairs 64(3): 312-327.

Heywood, Andrew (2007) Politics 3rd Ed. Palgrave: London.

Kandiyoti, Deniz A (1987) 'Emancipated but Unliberated? Reflections on the Turkish Case' Feminist Studies 13(2): 317-338.

Kara, İsmail (2011) Şeyhefendinin Rüyasındaki Türkiye Dergah Yayınları: İstanbul. 
Kuru, Ahmet (2009) Secularism and State Policies Toward Religion: The United States, France and Turkey Cambridge University Press: Cambridge.

Kuru, Ahmet (2007) 'Passive and Assertive Secularism: Historical Conditions, Ideological Struggles and State Policies Toward Religion World Politics 59(4): 568-594.

Kymlicka, Will (1989) Liberalism, Community and Culture Oxford University Press: Oxford and New York.

Mardin, Şerif (2000) The Genesis of Young Ottoman Thought: A Study in the Modernization of Turkish Political Ideas Princeton University Press: Princeton.

Özpek, Burak B (2012) 'Constitution-Making in Turkey after the 2011 Elections' Turkish Studies 13(2): 153-167.

Pippin, Robert (1992) 'The Modern World of Leo Strauss' Political Theory 20(3): 448-472.

Rawls, John (2003) A Theory of Justice $6^{\text {th }}$ Ed. Harvard University Press: Cambridge.

Robertson, Neil G (1998) 'The Closing of the Early Modern Mind: Leo Strauss and Early Modern Political Thought' Animus 3: 1-16, available at: http:// www2.swgc.mun.ca/animus/vol3.html.

Sandel, Michael (1998) Liberalism and the Limits of Justice Cambridge University Press: Cambridge.

Satana, Nil (2008) 'Transformation of the Turkish Military and the Path to Democracy' Armed Forces and Society 34(3): 357-388.

Strauss, Leo (1981) 'Progress or Return? The Contemporary Crisis in Western Civilization’ Modern Judaism 1(1): 17-45.

Strauss, Leo (1989) ‘The Three Waves of Modernity' in Hilail Gildin (Ed.) An Introduction to Political Philosophy: Ten Essays by Leo Strauss Wayne State University Press: Detroit.

Torfing, Jacob (1999) New Theories of Discourse: Laclau, Mouffe, Zizek Blackwell: Oxford.

Yavuz, Hakan M (2006) The Emergence of a New Turkey: Islam, Democracy and the AK Party University of Utah Press: Utah.

Yeğen, Mesut (2011) 'The Kurdish Question in Turkey: Denial to Recognition' in Marlies Casier and Joost Jongerden (Eds.) Nationalisms and Politics in Turkey: Political Islam, Kemalism and the Kurdish Issue Routledge: London and New York.

Zürcher, Erik J (1984) The Unionist Factor: The Role of the Committee of Union and Progress in the Turkish National Movement, 1905-1926 Brill: Leiden. 